\title{
Effects of Water Level Decline in Lake Urmia, Iran, on Local Climate Conditions
}

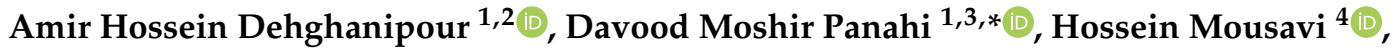 \\ Zahra Kalantari ${ }^{3,5}$ (D) and Massoud Tajrishy ${ }^{6}$ (D) \\ 1 School of Civil Engineering, Iran University of Science and Technology, Tehran 16846-13114, Iran; \\ A.Dehghanipour@tudelft.nl \\ 2 Faculty of Civil Engineering and Geosciences, Delft University of Technology, \\ 2628 CN Delft, The Netherlands \\ 3 Department of Physical Geography and Bolin Centre for Climate Research, Stockholm University, \\ SE-10691 Stockholm, Sweden; zahra.kalantari@natgeo.su.se \\ 4 Department of Civil and Environmental Engineering, AmirKabir University of Technology, \\ Tehran 15875-4413, Iran; hoseinmousavi@aut.ac.ir \\ 5 Navarino Environmental Observatory, 24001 Messinia, Greece \\ 6 Department of Civil Engineering, Sharif University of Technology, Tehran 11155, Iran; Tajrishy@sharif.edu \\ * Correspondence: moshirpanahi@natgeo.su.se
}

Received: 7 July 2020; Accepted: 28 July 2020; Published: 30 July 2020

check for updates

\begin{abstract}
Lake Urmia in northwestern Iran is the largest lake in Iran and the second largest saltwater lake in the world. The water level in Lake Urmia has decreased dramatically in recent years, due to drought, climate change, and the overuse of water resources for irrigation. This shrinking of the lake may affect local climate conditions, assuming that the lake itself affects the local climate. In this study, we quantified the lake's impact on the local climate by analyzing hourly time series of data on climate variables (temperature, vapor pressure, relative humidity, evaporation, and dewpoint temperature for all seasons, and local lake/land breezes in summer) for the period 1961-2016. For this, we compared high quality, long-term climate data obtained from Urmia and Saqez meteorological stations, located $30 \mathrm{~km}$ and $185 \mathrm{~km}$ from the lake center, respectively. We then investigated the effect of lake level decrease on the climate variables by dividing the data into periods 1961-1995 (normal lake level) and 1996-2016 (low lake level). The results showed that at Urmia station (close to the lake), climate parameters displayed fewer fluctuations and were evidently affected by Lake Urmia compared with those at Saqez station. The effects of the lake on the local climate increased with increasing temperature, with the most significant impact in summer and the least in winter. The results also indicated that, despite decreasing lake level, local climate conditions are still influenced by Lake Urmia, but to a lesser extent.
\end{abstract}

Keywords: Lake Urmia; local climate; temperature adjustment; lake/land breeze

\section{Introduction}

Climate conditions in lake basins can be affected by the lake itself, in addition to geographical factors, such as longitude, altitude, and large-scale climate variability [1]. The combined effects of these factors led to particular natural climate conditions in lake basins [2,3]. A few studies have examined the effects of lakes on the local climate and have found marked influences. For instance, the Great Lakes have been shown to play a significant role in the local climate by: (1) damping natural temperature changes in all seasons, leading to cooler summers and warmer winters; (2) increasing cloud cover, precipitation, and snowfall over and leeward (downwind) of the lakes in winter; (3) decreasing summertime convective clouds and rainfall over the lakes [4,5]; $(4)$ giving rise to mild cooling breezes 
that help orchards and vineyards on the lakeshore to flourish; (5) exerting a harshening effect on snow and ice storms $[6,7]$.

On comparing climate parameters and changes in the surface level of the Dead Sea, [8] found that decreasing lake level led to a decrease in relative humidity and cool lake breezes, resulting in increases in temperature and evaporation from the local region around the lake. Ref. [9] examined the effects of artificial and natural lakes on the local climate and found that the presence of a lake can either enhance or reduce the impact of large-scale climate changes in the local region around the lake.

The water level in Lake Urmia, the largest lake in Iran and the second largest saltwater lake in the world, has dramatically declined in recent years, due to human and climate change drivers $[10,11]$. The reasons for the decreases in the area and level of Lake Urmia, and management strategies to restore the lake, have been addressed by many researchers over recent years. Most of this research has emphasized the role of human activities, drought, and climate change in drying out the lake e.g., [12-15]. The different management scenarios proposed to save Lake Urmia are based on reducing water consumption in the agriculture sector and on adaptation to drought and climate change e.g., [16-18].

However, the effect of changes in Lake Urmia on the local climate have not been addressed. In fact, there are no data in the literature confirming that the lake has an impact on the local climate in surrounding areas, which is essential information when studying the effect of changes in lake level on local climate change. In order to identify the impact of Lake Urmia on the local climate, in the first part of this study we compared time series data on climate parameters measured at meteorological stations in Urmia (close to the lake) and Saqez (far from the lake) during the period 1961-2016. We then divided data for the period 1961-2016 into two periods representing normal lake level (1961-1995) and low lake level (1996-2016) and investigated the effect of decreasing lake level on the local climate.

\section{Study Site}

Lake Urmia and its basin (area approximately 52,000 $\mathrm{km}^{2}$ ) are located in the semi-arid region of northwestern Iran $\left(35^{\circ} 40^{\prime}-38^{\circ} 30^{\prime} \mathrm{N}, 44^{\circ} 07^{\prime}-47^{\circ} 53^{\prime} \mathrm{E}\right.$ ) (Figure 1a). The basin is endorheic (closed), with a mean annual precipitation of $400 \mathrm{~mm}$ (most of which falls in winter and spring), a mean annual temperature of $20^{\circ} \mathrm{C}$ [14], and a mean annual relative humidity ranging between 52 and $64 \%$. More than five million people live in the Urmia basin and agriculture plays a significant role in the livelihoods of these people [19]. The average depth of the lake is $6 \mathrm{~m}$ and the maximum depth is $16 \mathrm{~m}$. The lake wetland was registered as an international Ramsar site in 1975 and as a UNESCO Biosphere Reserve in 1977. The water level and area of Lake Urmia have decreased dramatically since the late 1990s [11]. Time series of Lake Urmia level from 1965 to 2018 are shown in Figure 1b. The location of the two meteorological stations from which observed data on climate parameters were obtained for the present analysis are shown in Figure 1a. 

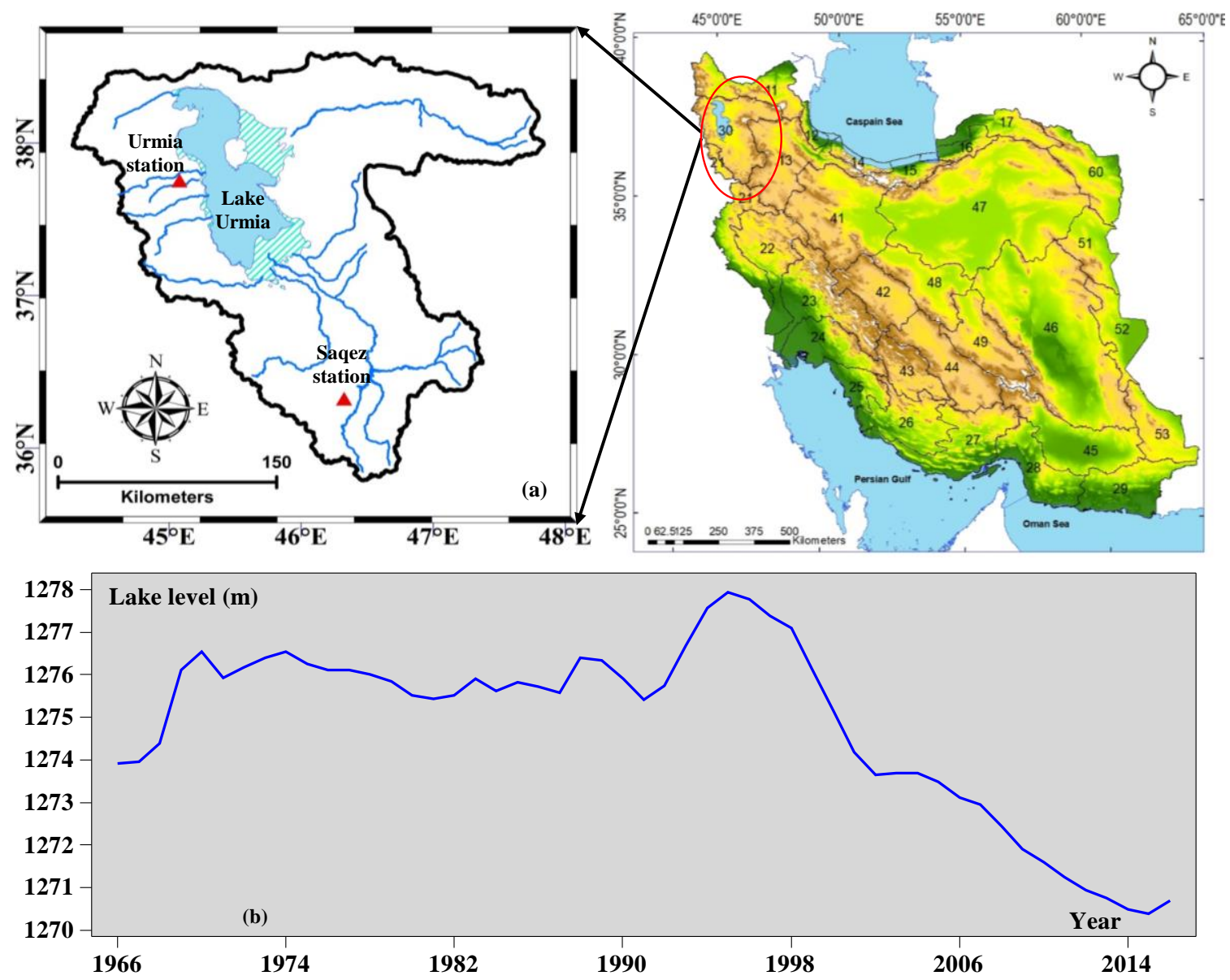

Figure 1. (a) Maps showing the location of Lake Urmia and its basin in northwestern Iran and of the two meteorological stations from which data were taken, and (b) changes in the water level in Lake Urmia, 1965-2018.

\section{Methodology}

\subsection{Local Breezes around Lake Urmia}

Local breezes are winds that regularly blow in some sub-regions due to unique geographical features such as mountains and lakes, and regional thermal differences caused by these features. The range of these local breezes is limited, and they are usually restricted to the lower layers of the atmosphere, so they only affect a small region. In the area closest to lakes, temperature differences between the land and water surface during the day and night can give rise to the formation of a local lake/land breeze. The water surface is slower to heat up than the surrounding land during the day, so the temperature of the land increases earlier than the temperature of the water surface. The air above the water surface is then colder, denser, and more pressurized than the air above the land surface, and therefore the breeze blows from lake to land (lake breeze) during the day, beginning in the morning and reaching its maximum velocity at noon (Figure 2a). As the sun goes down, the opposite occurs, as the land cools more quickly than the water. The temperature of the land surface decreases earlier than the temperature of the land surface during the night and becomes colder, so the breeze blows from the land to the lake (land breeze) (Figure 2b). The lake breeze is generally stronger than the land breeze since the temperature contrast between land surface and lake surface is higher during the day than at night.

Land/lake breezes are quite noticeable in the area around Lake Urmia during the summer, when the temperature difference between land surface and lake surface is high and large-scale winds are limited. 
In this study, the local breeze was quantified only at Urmia meteorological station, which is located near the lake, and only in summer.

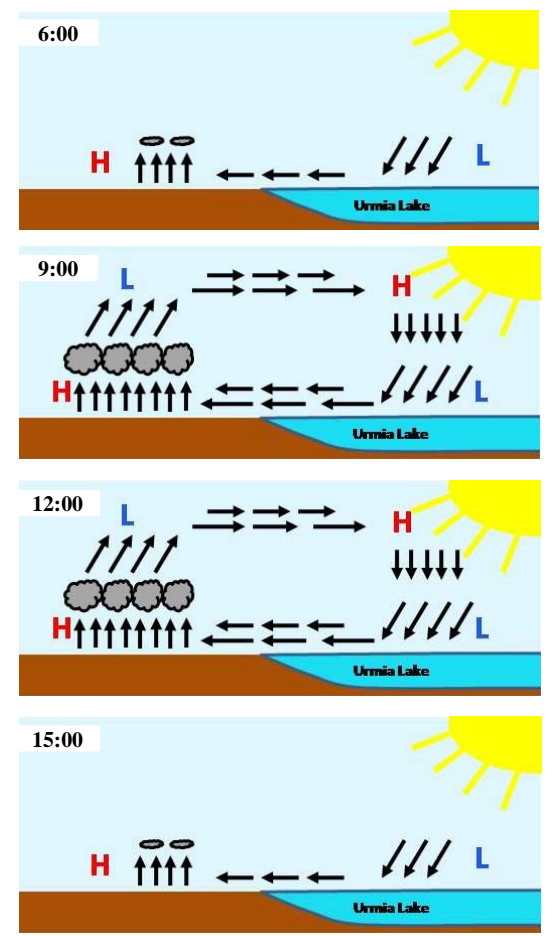

(a)

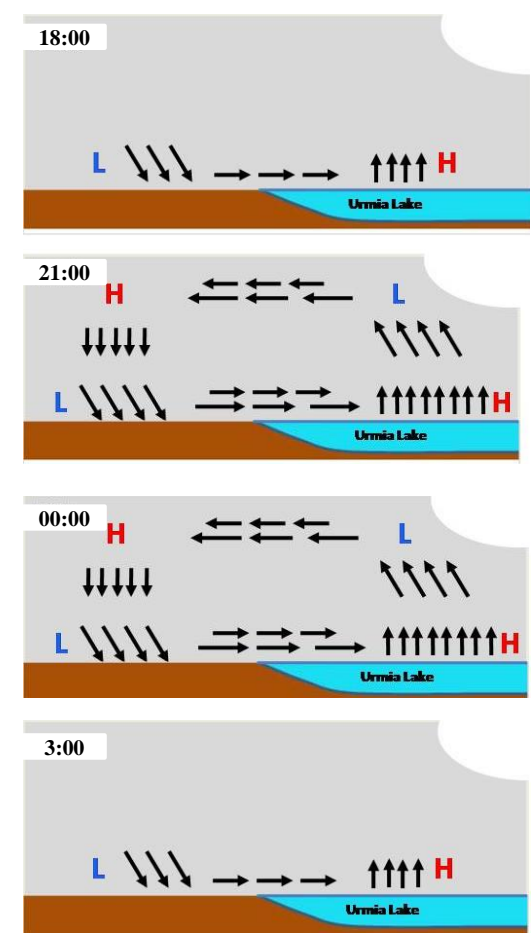

(b)

Figure 2. Schematic diagrams showing formation of (a) lake breeze during the day and (b) land breeze during the night, at the edge of Lake Urmia.

\subsection{Vapor Pressure, Relative Humidity, and Dewpoint Temperature}

Water vapor is the most important greenhouse gas in the atmosphere, and the amount of water vapor in the air determines the humidity. The maximum amount of water vapor that can be present in the air-i.e., the saturation point — is a function of temperature (Figure 3). The air is saturated by water vapor in two ways: (i) by increasing the humidity at a constant temperature until the saturation point is reached - the vapor pressure in this condition is called saturated vapor pressure and is represented by $e_{s}$; (ii) by decreasing the temperature at a constant vapor pressure until the saturation point is reached-the temperature in this condition is called dewpoint temperature and is represented by $T_{D E W}$ (Figure 3).

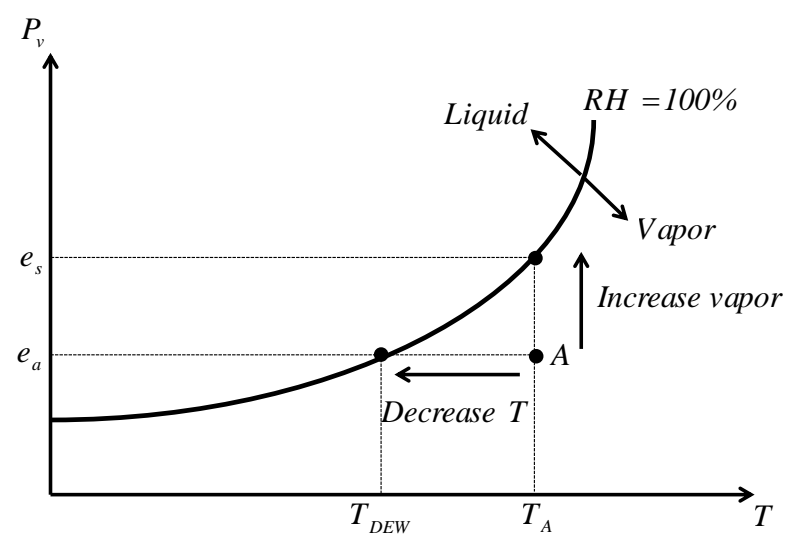

Figure 3. Graph of vapor pressure $\left(P_{v}\right)$ against temperature $(T)$, showing the position of saturated vapor pressure $\left(e_{s}\right)$ and dewpoint temperature $\left(T_{D E W}\right) . R H=$ relative humidity. 
Relative humidity $(R H)$ is the ratio of vapor pressure in the air $\left(e_{a}\right)$ to saturated vapor pressure $\left(e_{s}\right)$. It is usually expressed as a percentage. Relative humidity is a function of temperature, since a decreasing temperature leads to a decrease in saturated vapor pressure and results in increasing relative air humidity, and vice versa (see Figure 3).

Evaporation from Lake Urmia leads to changes in water vapor in the region around the lake, resulting, in turn, in changes in vapor pressure parameters, relative humidity, and dewpoint temperature.

\subsection{Methodology}

The main aims of this study were to quantify the effect of Lake Urmia on the local climate and examine how changes in the lake level have affected the local climate. The meteorological stations at Urmia and Saqez were chosen as the sources of climate data for two main reasons: (i) they have a large amount of time series data (since 1961) [20]; (ii) Urmia station is the closest station to Lake Urmia (30 km to the lake center) and Saqez is the farthest from Lake Urmia (185 km to the lake center) (see Table S1 in Supplementary Materials (SM) for details). Hourly time series of climate parameters in winter, spring, summer, and autumn in the period 1961 to 2016 were selected for the analysis.

At Urmia station, there is a high possibility of Lake Urmia and water level variations in the lake affecting climate variables, while Saqez station is most likely too far from the lake for climate variables to be affected. Saqez station is also located in mountainous terrain, which can overcome any lake effects. To investigate the overall impact of the lake on the local climate, hourly average time series of climate variables measured at the two stations in all seasons were compared, based on differences in statistical indicators (average, median, deviation from line 1:1, and standard deviation). To investigate the impact of lake level change on the local climate change, the study period was divided into two (1961-1995 and 1996-2016). The split-point chosen was 1995 because the maximum level of the lake occurred in that year and since then the lake level has declined (Figure 1b). In each period, hourly averages of climate parameters in winter and summer were compared for the two stations, since these seasons experience the least and most change, respectively, in climate conditions through the day and night.

The climate variables assessed were temperature, vapor pressure, relative humidity, dewpoint temperature, and evaporation at the Urmia and Saqez stations. Local lake breeze/land breeze effects were investigated only for the Urmia station and only in the summer season, when calm conditions prevail in the region.

\section{Results and Discussions}

\subsection{Effects of Lake Urmia on the Local Climate}

A schematic diagram of land/lake breeze directions is shown in Figure 4a. Wind direction on an hourly scale at Urmia station during the day and night in summer is shown in Figure $4 b, c$, respectively. The results indicated that the prevailing wind direction is related to lake breeze in daytime (06:00 to 15:00 $\mathrm{h}$ ) and to land breeze at night (18:00 to 03:00 h). Full descriptions of wind direction (land direction, lake direction, other direction) are provided in Table S2 in SM. The speed of the lake breeze is around 3.5 knots at 6:00, 9:00, and 12:00 h, but decreases to around 2.6 knots at 15:00 h (afternoon), due to the reduction in temperature difference between lake and land surface in the afternoon (Figure $4 \mathrm{~d}$ ). The average speed of the land breezes is 2.5 knots and it varies within a narrower range, due to the smaller difference in temperature between lake and land surface at night (Figure 4d). 

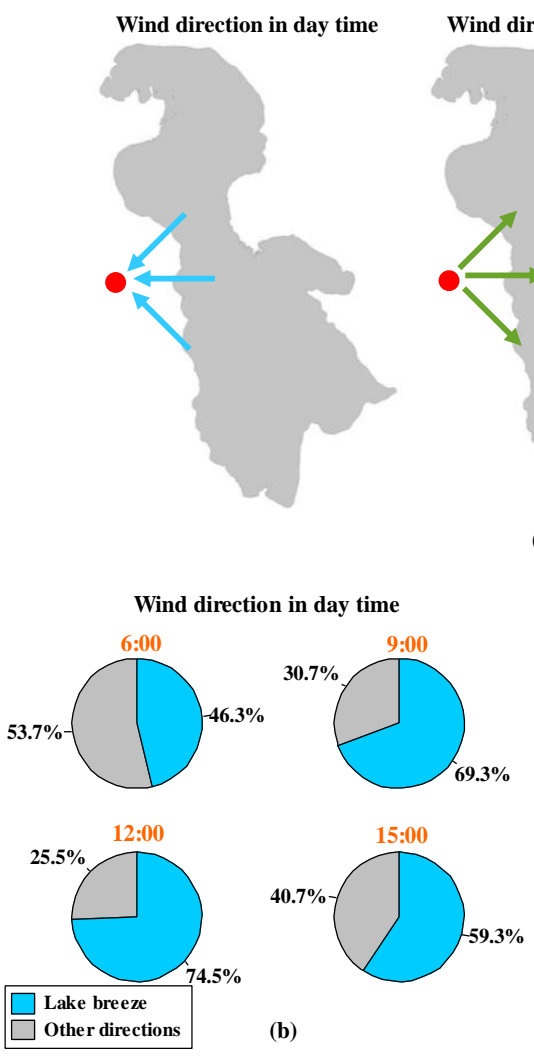

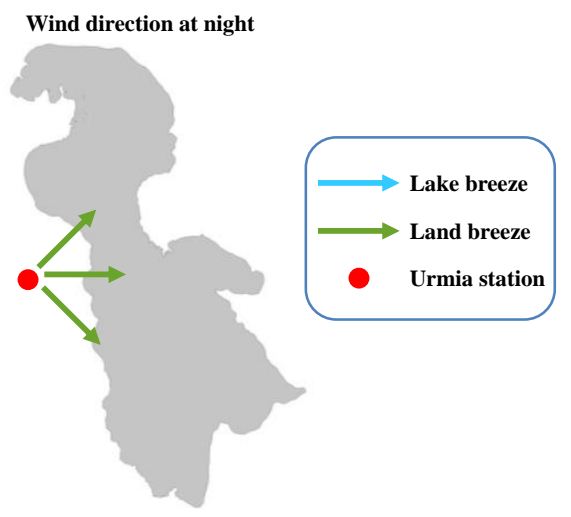

(a)
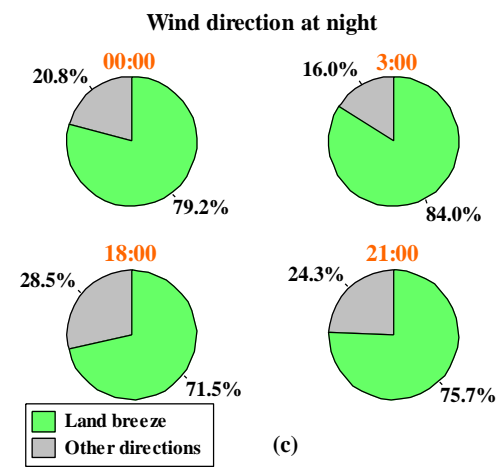

(c)

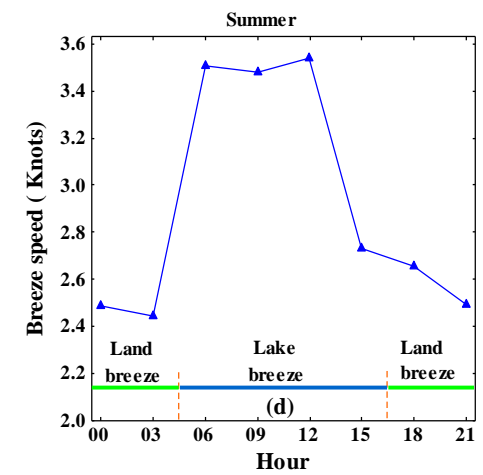

Figure 4. (a) Schematic diagram of land/lake breezes direction (inspired by [21]). Hourly wind direction at Urmia meteorological station in summer $(\mathbf{b})$ in daytime and (c) at night. (d) Speed of lake breeze (6:00 to $15: 00 \mathrm{~h})$ and land breeze (18:00 to 03:00 h) at Urmia station.

Scatterplots and boxplots showing the seasonal pattern in maximum temperature $\left(T_{\max }\right)$, minimum temperature $\left(T_{\min }\right)$, and the difference between maximum and minimum temperature $\left(T_{\max }-T_{\min }\right)$ at Urmia and Saqez stations are presented in Figure 5, where average values of the climate variables are shown with black dots in the boxplots. The results showed that the maximum temperature at Urmia station was lower than that at Saqez station during summer, spring, and autumn, but was similar in winter (Figure 5a). The corresponding boxplot for the two stations showed that the mean and median values and range of variation in maximum temperature were all lower at Urmia station than at Saqez station in summer, but that the difference decreased in spring and autumn and practically disappeared in winter (Figure 5b).

For the minimum temperature at Urmia station, most points in all seasons were located above the line 1:1-i.e., the minimum temperature was higher at Urmia than at Saqez station (Figure 5c). The mean, median, and range of variation in minimum temperature at Urmia station were also higher than at Saqez station, with the difference between the stations being highest in summer and lowest in winter (Figure $5 \mathrm{~d}$ ). 

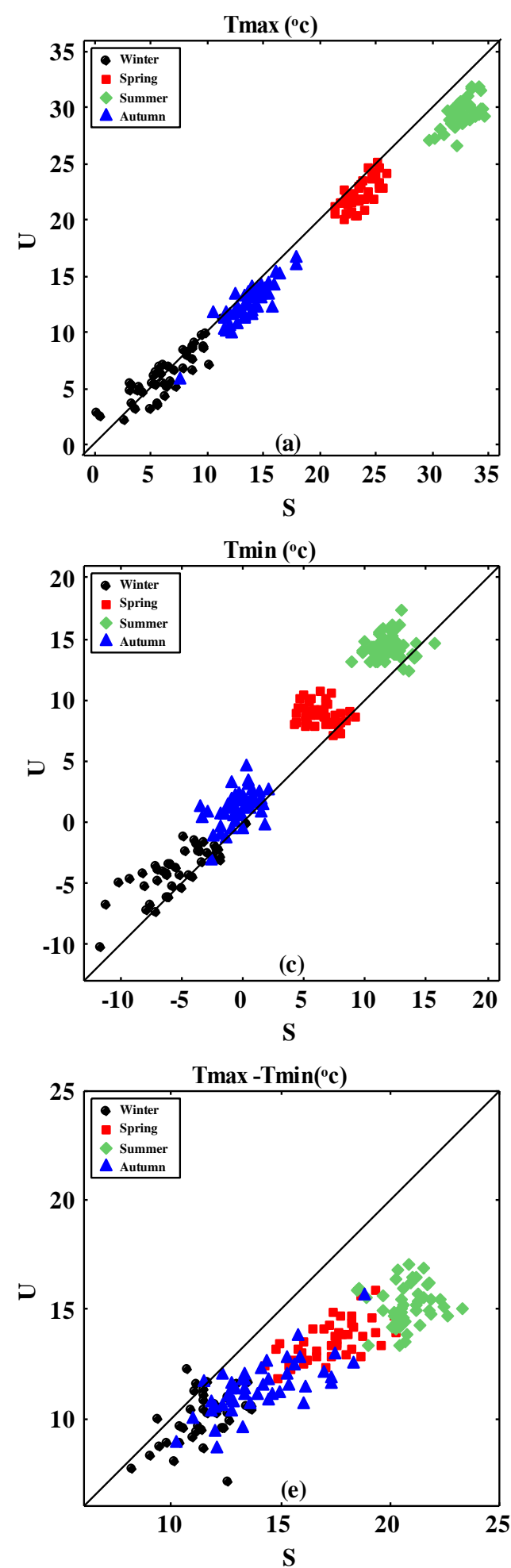
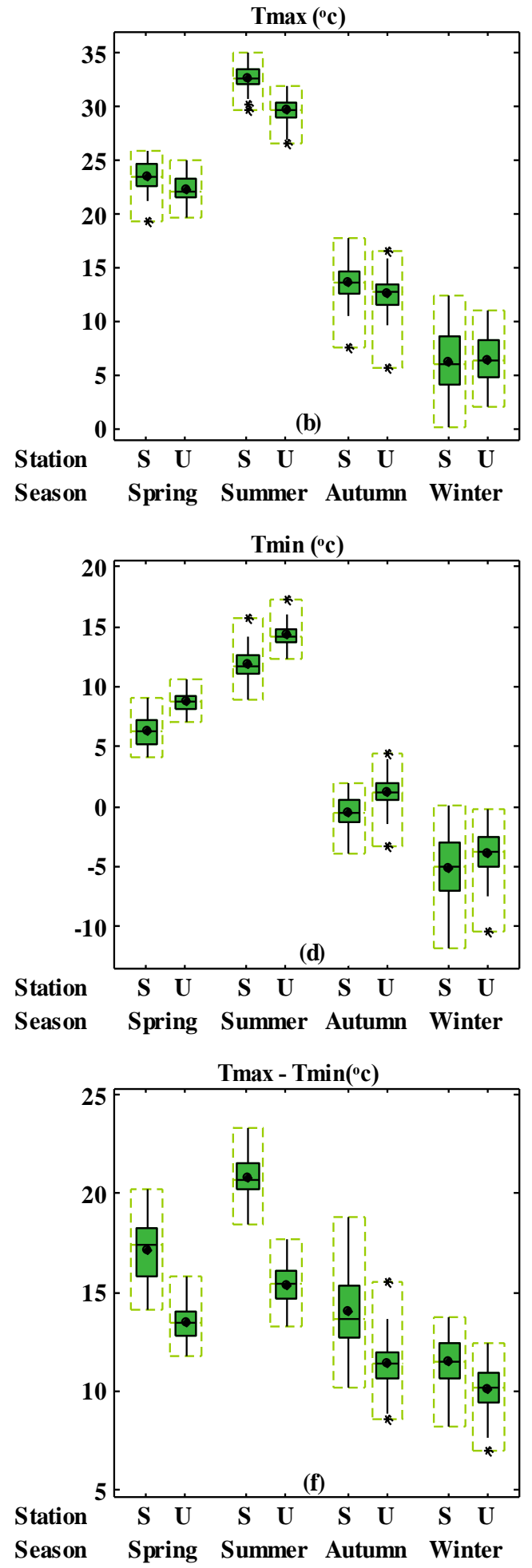

Figure 5. Seasonal patterns in maximum and minimum temperature. Scatterplots of (a) maximum temperature $\left(T_{\max }\right),(\mathbf{c})$ minimum temperature $\left(T_{\min }\right)$, and (e) difference between maximum and minimum temperature $\left(T_{\max }-T_{\min }\right)$ in the different seasons at Urmia station (U) and Saqez station (S). $(\mathbf{b}, \mathbf{d}, \mathbf{f})$ The corresponding boxplots.

The points for the temperature fluctuation range (difference between maximum and minimum temperature) at Urmia station compared with Saqez station in all seasons were almost all below the line 1:1-i.e., the temperature fluctuations were smaller during all seasons at Urmia than at Saqez 
station (Figure 5e). The mean, median, and range of variation in temperature fluctuations were also smaller at Urmia than at Saqez station (Figure 5f). The difference between the stations in mean, median, and range of variation in temperature fluctuations was highest in summer and lowest in winter.

The analysis of maximum and minimum temperatures thus showed that Lake Urmia played a significant role in temperature regulation in the local region, resulting in particular in cooler summers and warmer winters in the plains area surrounding the lake. The results also showed that the effects of the lake in temperature regulation in the region were more pronounced in summer. The lake lowered the air temperature and reduced the temperature fluctuations in the local region around the lake in summer, while the temperature fluctuations were high in areas not affected by the lake (Saqez).

The seasonal pattern in vapor pressure at 03:00 $\mathrm{h}$ (VP3) and 15:00 $\mathrm{h}$ (VP15) at Urmia and Saqez stations is shown in Figure 6. These times were chosen because they are the points when the temperature reaches its minimum and maximum value in daytime and at night, respectively. The scatterplots of VP3 (Figure 6a) and VP15 (Figure 6c) at Urmia station, compared with Saqez station, showed that both were higher at Urmia in summer, spring, and autumn, but similar at both stations in winter. The mean, median, and range of variation in both VP3 and VP15 were also higher at Urmia station than at Saqez in summer, spring, and autumn, but similar at both stations in winter (Figure $6 \mathrm{~b}, \mathrm{~d}$ ). The most significant differences between mean and median VP3 and VP15 at the two stations were in summer, spring, autumn, and winter. Analysis of the results showed that higher temperatures in summer increased evaporation from the lake and increased the vapor pressure in the local region around the lake.
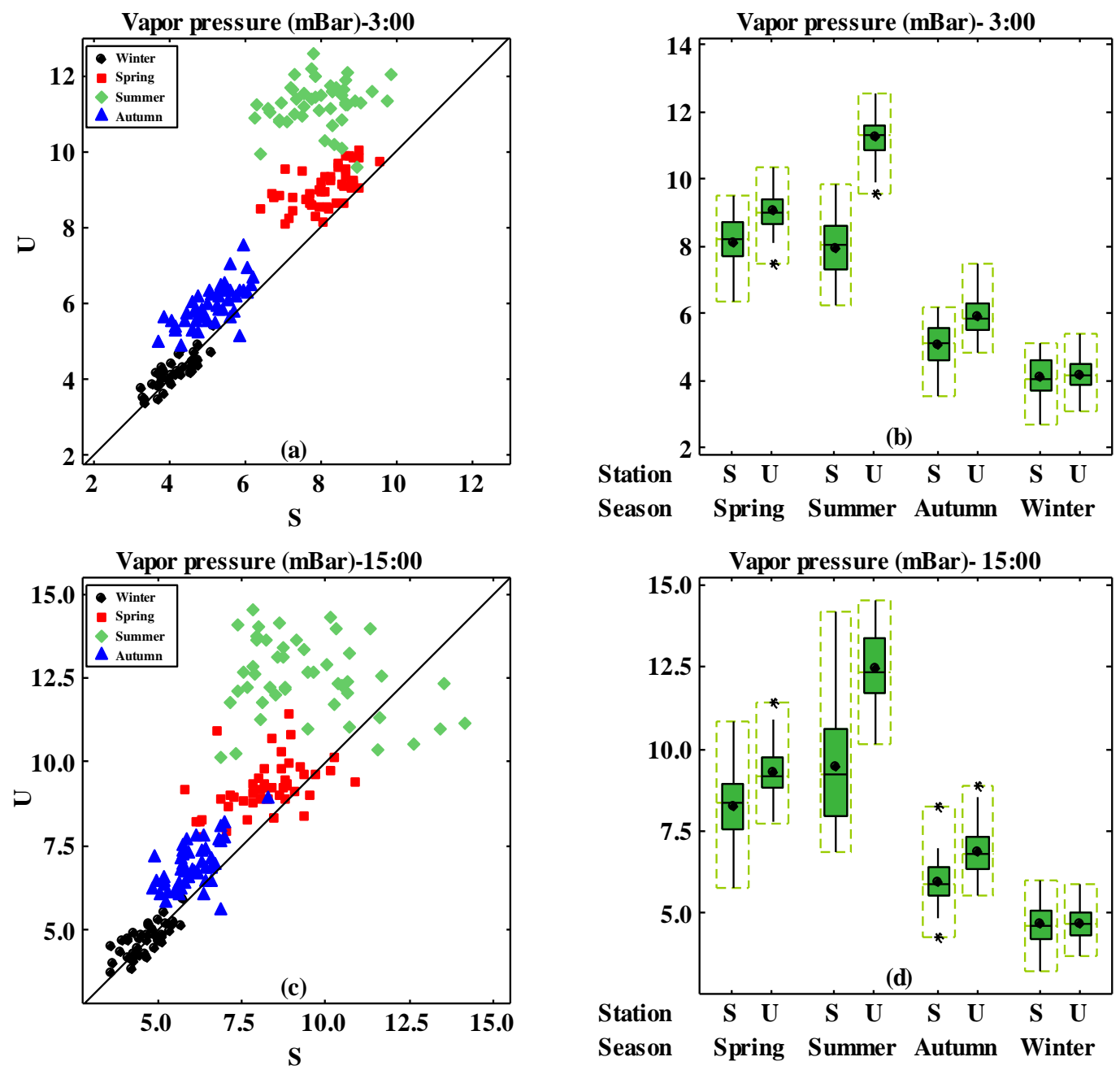

Figure 6. Seasonal patterns in vapor pressure. Scatterplots of vapor pressure at (a) 03:00 h and (c) 15.00 $\mathrm{h}$ in the different seasons at Urmia station $(\mathrm{U})$ and Saqez station $(\mathrm{S})$. (b,d) The corresponding boxplots. 
The seasonal pattern in dewpoint temperature at 03:00 $\mathrm{h}$ and 15:00 $\mathrm{h}$ (DPT3 and DPT15, respectively) for Urmia and Saqez stations is shown in Figure 7. Since an increase in vapor pressure causes an increase in the dewpoint temperature, the scatterplots for DPT3 and DPT15 (Figure 7a,c, respectively) were similar to the scatterplots for VP3 and VP15 (Figure 6a,c, respectively). The differences between the stations (deviation from the 1:1 line) were highest in summer and lowest in winter. The mean, median, and range of variation in DPT3 and DPT15 were higher at Urmia than at Saqez station in summer, spring, and autumn, whereas they were similar at both stations in winter.
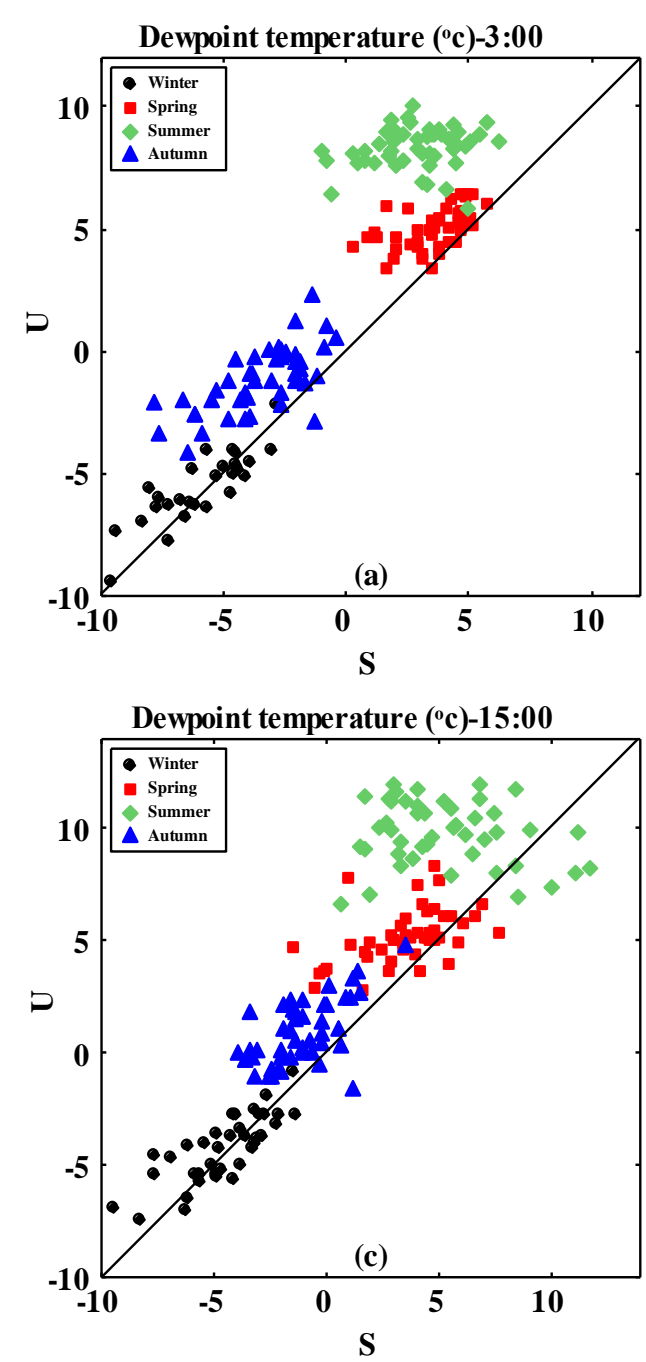
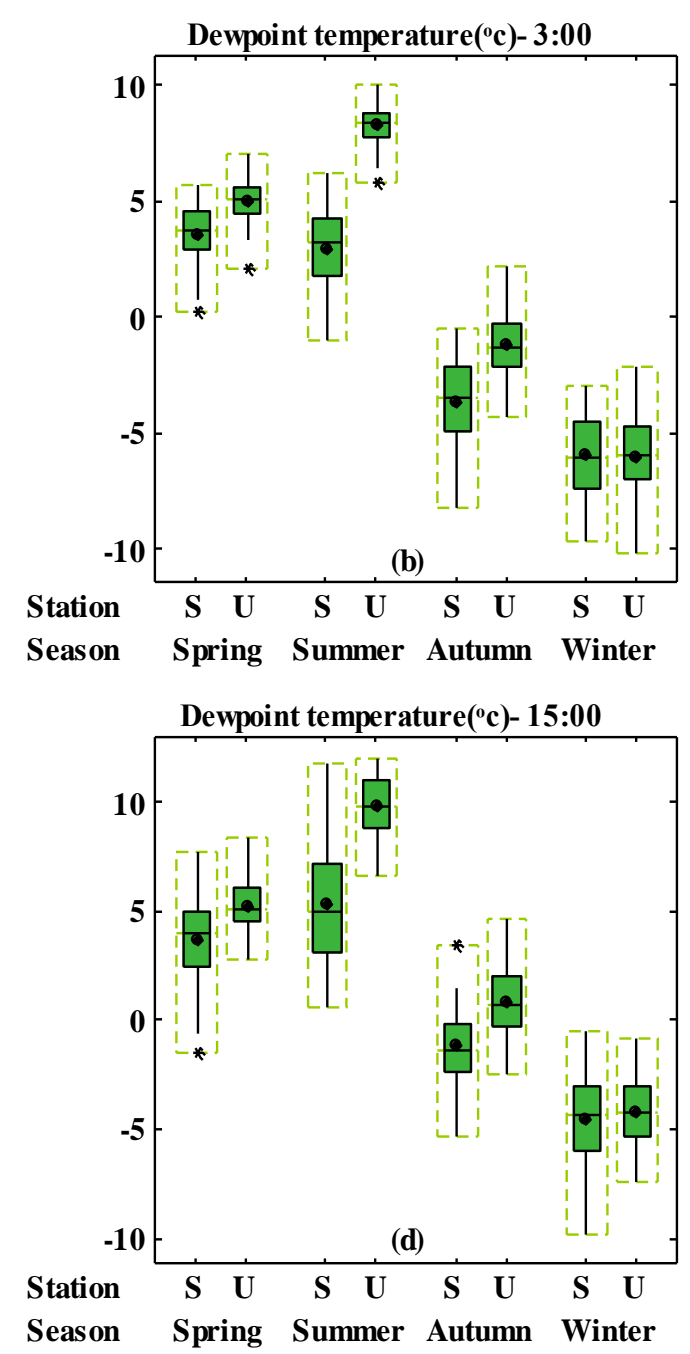

Figure 7. Seasonal pattern in dewpoint temperature. Scatterplots of dewpoint temperature at (a) 03:00 h and (c) $15.00 \mathrm{~h}$ in the different seasons at Urmia station (U) and Saqez station (S). $($ b,d) The corresponding boxplots.

The seasonal pattern in evaporation at the two stations is shown in Figure 8. The scatterplot of evaporation indicated that evaporation at both Urmia and Saqez stations was almost zero in winter, due to the low temperatures (Figure 8a). However, evaporation was lower at Urmia than at Saqez station in the other seasons. As mentioned, increasing temperature led to an increase in evaporation from the lake, which resulted in increasing vapor pressure and decreasing evaporation in the local region around the lake. The most significant differences between the stations (deviations from the 1:1 line) were in spring and summer (Figure 8a). The boxplots for evaporation at the two stations showed that the average, median, and range of variation were lower at Urmia than at Saqez in summer, spring, and autumn. 

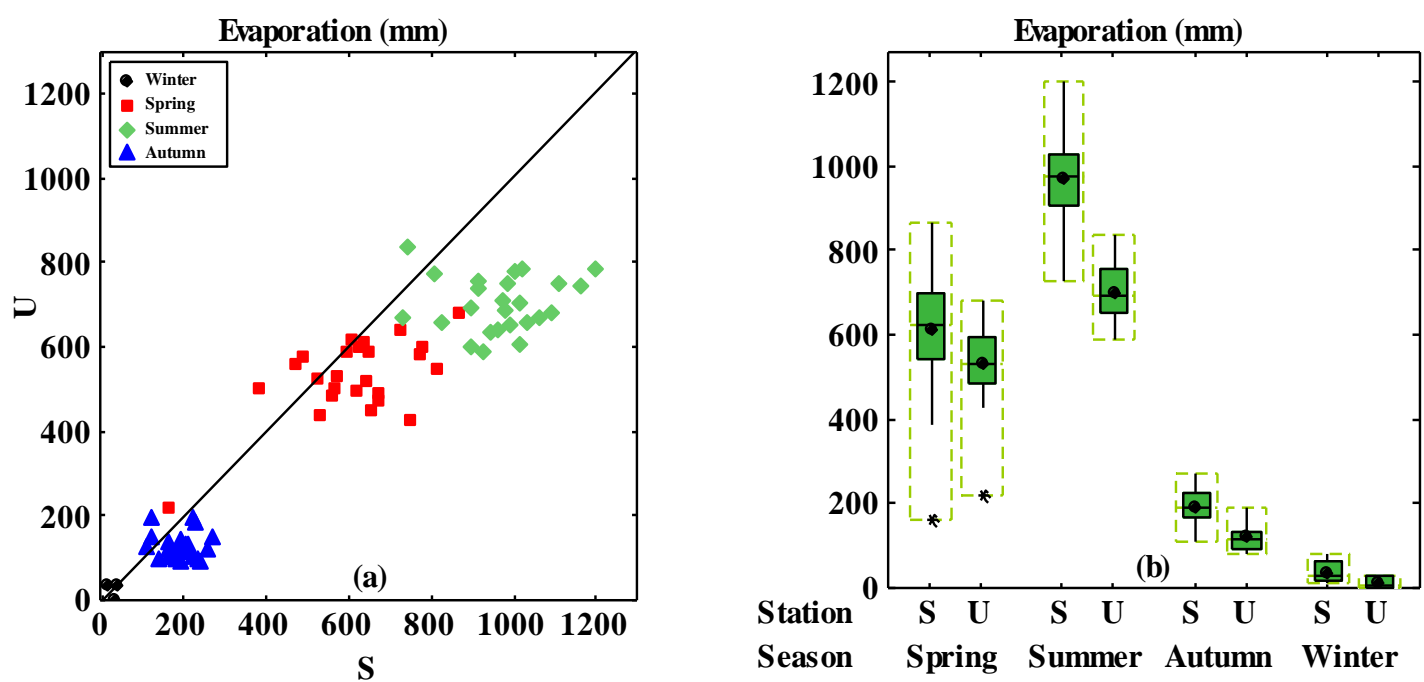

Figure 8. Seasonal pattern in evaporation. (a) Scatterplot of evaporation in the different seasons at Urmia station (U) and Saqez station. (b) The corresponding boxplot.

The seasonal pattern in relative humidity at 03:00 $\mathrm{h}$ and 15:00 $\mathrm{h}$ (RH3 and RH15) at the two stations is shown in Figure S1 in SM. Relative humidity is inversely related to temperature, with increasing temperature leading to an increase in saturation vapor pressure and a decrease in relative humidity (see Figure 3). Therefore, RH3 and RH15 were higher in winter than in summer. Another point is that rising temperature led to increasing vapor pressure in the local region around the lake, resulting in higher relative humidity in the local area around the lake. As can be seen in Figure S1, the mean, median, and range of variation in RH3 and RH15 were higher at Urmia than at Saqez station in all four seasons.

\subsection{Impact of Lake Level Reduction on Local Climate Change}

To investigate the effects of decreasing lake level on the local climate, the periods with normal level (1961-1995) and low water level in the lake (1996-2016) were compared hourly for the two stations. These comparisons were made for summer (when the lake has the most significant impact on the local climate) and winter (when the lake has the least impact on the local climate).

The long-term hourly average of the speed of lake/land breezes in summer in the two periods is presented in Figure 9. As can be seen, the hourly speed of both lake and land breezes was lower in the period with low lake level than in the period with normal lake level. For instance, the speed of the lake breeze in the period with normal lake level (1961-1995) was almost equal between 9:00 and 12:00 $\mathrm{h}$, and the peak occurred at 06:00 $\mathrm{h}$. In the period with low lake level (1996-2016), the peak lake breeze occurred at 12:00 $\mathrm{h}$. The speed of the lake breeze in the low lake level period decreased by about $20 \%, 14 \%$, and $5 \%$ at 6:00 h, 9:00 h, and 15:00 h, respectively, compared with that in the normal period (Figure S2 in Supplementary Materials (SM)). The speed of the land breeze in the period with low lake level decreased by between $5 \%$ and $14 \%$ during different hours of the day compared with that in the normal lake level period (Figure S2). These changes reflect the effects of the reduction in the area and level of Lake Urmia on lake/land breezes.

Comparisons of long-term hourly average summer temperatures at the two stations in the normal and low lake level periods revealed that the minimum temperature at Urmia was higher than at Saqez station, but the maximum temperature was lower (Figure 10a). Therefore, the hourly temperature variation was less at Urmia station than at Saqez station. The hourly mean summer temperature change at both Urmia and Saqez stations was $-2 \%$ and $5 \%$ in the period with normal and low lake levels, respectively (see Figure S3a in SM). 


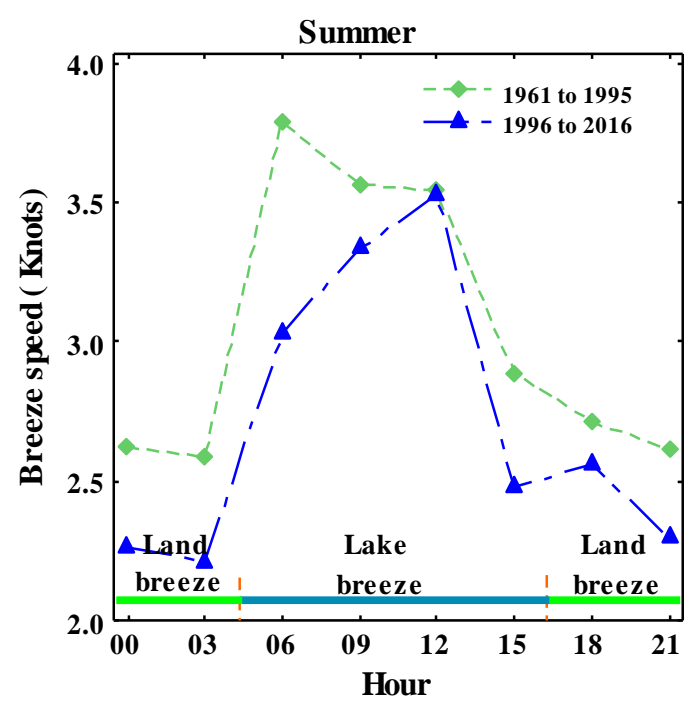

Figure 9. Speed of summer lake and land breezes at Urmia meteorological station in sub-periods with normal (1961-1995) and low level (1996-2016) in Lake Urmia.

The data on long-term hourly average winter temperatures at the two stations in the periods with normal and low lake level showed that the lake did not have considerable effects at Urmia station in winter (Figure 10b). In winter, the hourly average temperature at both Saqez and Urmia stations was higher in the period with low lake level than in the normal lake level period, and the increase in temperature was greater at Urmia station than at Saqez station (Figure S3b). This increase in temperature can be attributed to climate change outside the local scale $[19,22]$.

The hourly average vapor pressure in summer at the two stations in the periods of normal and low lake levels displayed less variation and higher hourly values at Urmia station than at Saqez station (Figure 10c). These changes can be attributed to the effects of Lake Urmia on vapor pressure in the local region around the lake. The results confirmed that the vapor pressure at the two stations decreased in the period of low lake level compared with the period of normal lake level, which can be attributed to climate variability on a coarser spatial scale. Note that the changes in vapor pressure were less at Urmia station than at Saqez station, which indicates the role of the lake on vapor pressure.

Dewpoint temperature is a direct function of vapor pressure (Figure 3). Temperature changes in summer were negligible for the two stations, so the saturation vapor pressure did not change much, and therefore relative humidity in summer was also a direct function of vapor pressure. Consequently, similar hourly changes were seen in dewpoint temperature (Figure 10e) and relative humidity (Figure 10g) in summer.

In winter, the variation in hourly average vapor pressure at the stations in the periods with normal and low lake levels was similar (Figure 10d), due to the reduction in the lake's effects on the vapor pressure at Urmia in winter. The results showed that, at both stations and every hour, the vapor pressure increased in the period of low lake level compared with normal lake level. This was due to rising temperatures in winter and increasing evaporation, which led to increasing vapor pressure. Because dewpoint temperatures are directly related to water vapor pressure, there were similar changes in dewpoint temperature in winter (Figure 10f). As mentioned earlier, increasing temperature increased saturated vapor pressure, which reduced the relative humidity. As shown in Figure 10h, the hourly changes in relative humidity in winter were inversely related to the hourly changes in temperature, and this decrease in relative humidity per hour was due to climate variability at a coarser scale. 

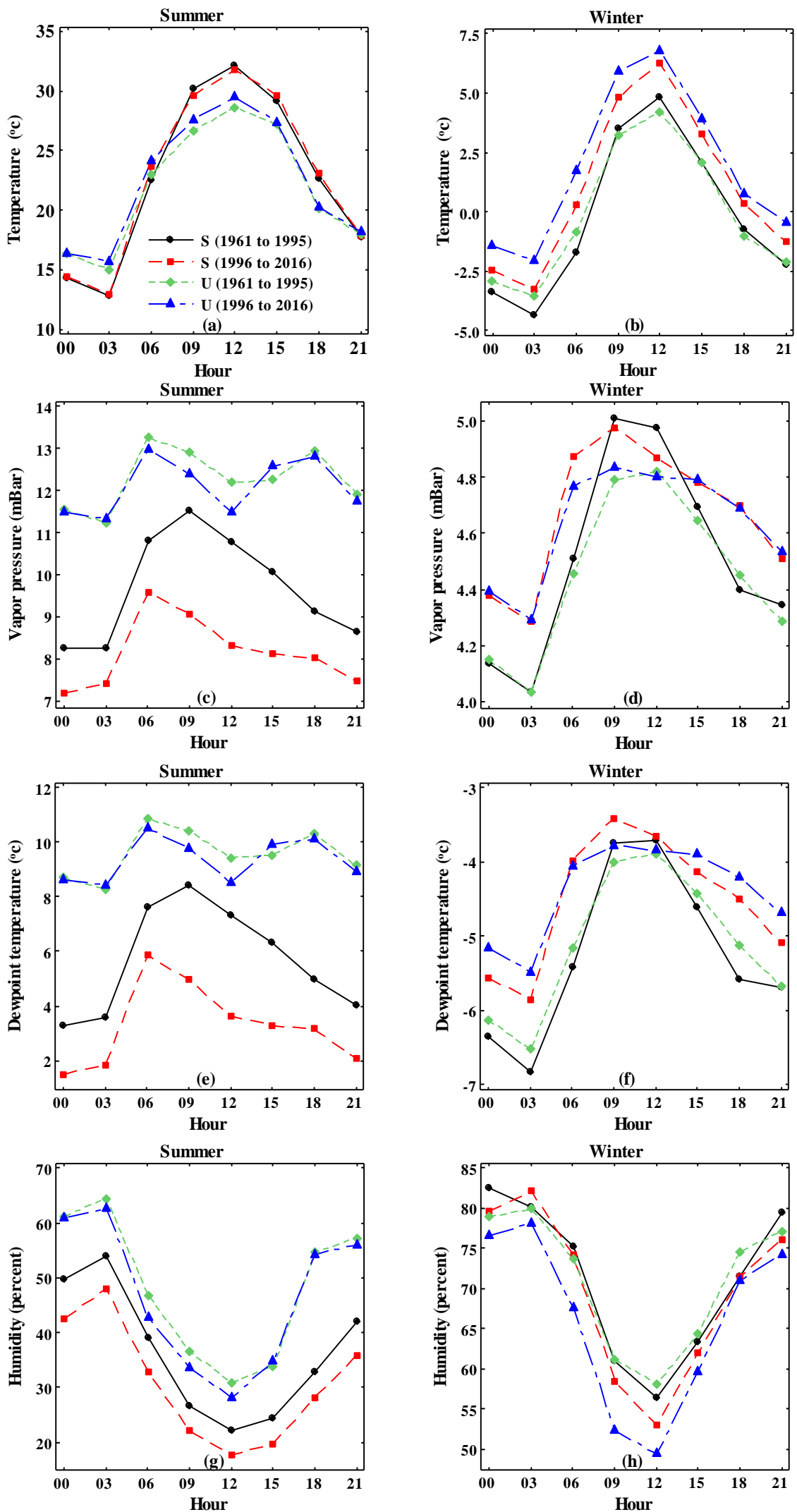

Figure 10. Hourly values of climate parameters at Urmia (U) and Saqez (S) meteorological stations in periods with normal (1961-1995) and low (1996-2016) lake level: (a) temperature in summer, (b) temperature in winter, (c) vapor pressure in summer, (d) vapor pressure in winter, (e) dewpoint temperature in summer, (f) dewpoint temperature in winter, (g) relative humidity in summer, and $(\mathbf{h})$ relative humidity in winter. 


\subsection{Contribution of Lake Urmia to Local Climate Conditions}

In this study, we investigated the effect of Lake Urmia on the local climate by comparing temperature, vapor pressure, dewpoint temperature, evaporation, and relative humidity at meteorological stations close to and far from the lake (Urmia and Saqez, respectively). The results showed a smaller temperature fluctuation range, lower mean maximum temperature, and higher mean minimum temperature at Urmia station compared with Saqez station, which resulted in cooler summers and warmer winters at Urmia. Although Urmia station $(1330 \mathrm{~m}$ asl $)$ is at lower elevation than Saqez station (1520 m asl), the lower mean maximum temperature at Urmia station is due partly to the lake effect. The heat capacity of water is higher than that of the land, resulting in lower temperature fluctuations in the lake compared with the land during the day and at night. Therefore, Lake Urmia adjusts the temperature of surrounding areas.

Vapor pressure, dewpoint temperature, and relative humidity were higher at Urmia than at Saqez station, but the evaporation rate was lower at Urmia and the fluctuations in these variables were smaller than at Saqez station. These results show that water vapor at Urmia station is higher than at Saqez station, the main reason being evaporation from the surface of Lake Urmia.

We quantified the effect of Lake Urmia on the formation of local breezes by analyzing the speed and direction of wind at Urmia station. The results indicated that local lake and land breezes in summer, formed due to the existence of Lake Urmia, are the dominant winds in the daytime and at night, respectively. The reversal of local breeze direction (from lake breezes to land breezes, and vice versa) and the change in speed during different hours of the day are due to changes in the temperature difference between land and lake surface during the day and night. The seasonality analysis can exhibit different spatial patterns caused by the variability of physical properties [21]. Although more than one meteorological station is needed for the seasonality variation analysis of breeze properties, they were not available in this study.

\subsection{Effect of Water Level Change in Lake Urmia on Local Climate Conditions}

We investigated the effects of decreasing lake level on the local climate by dividing the data into a period with normal level in the lake (1961-1995) and a period with low water level in the lake (1996-2016), and comparing climate variables in these periods at Urmia and Saqez stations. The results showed lower speed of lake and land breezes in the period with low lake water level compared with the normal water level period, and the timing of the peak in lake breeze also changed. These changes show the effects of lake water level reduction on lake/land breezes.

Summer temperature at both stations in the low lake level period was close to that in the normal lake level period. However, winter temperature at both stations in the low lake level period increased compared with the normal lake level period, and the increase was greater at Urmia station. During summer, vapor pressure, dewpoint temperature, and relative humidity at Urmia station during the low water level period were close to the values in the normal water level period. However, these variables decreased during winter at Urmia station. Overall, the results showed that, in the current low water period, Lake Urmia still plays an essential role in the local climate in summer, but its influence is significantly reduced in winter.

In this study, we focused on the quantification of the effects of Lake Urmia on the local climate. More research is required to quantify and assess the effect of local climate (change) on vegetation cover extent and pattern, crop type selection, and crop yield.

\section{Conclusions}

In addition to global (large-scale) climate variability, the local climate in areas near seas and lakes can be affected by the water body. This study showed that Lake Urmia in northwestern Iran affects the local climate of the surrounding area. However, Lake Urmia has experienced a dramatic decline in 
water level and area since 1998, with the main turning point being 1995. This study examined whether this decline in water level has altered the influence of Lake Urmia on the local climate.

Hourly time series of climate variables (temperature, relative humidity, vapor pressure, dewpoint temperature, and evaporation in all seasons, and local lake/land breezes in summer) at Urmia and Saqez meteorological stations (30 and $185 \mathrm{~km}$ from the lake center, respectively) in the period 1961-2016 were compared. The results showed that the lake generates lake and land breezes in the summer, and that the reduction in lake level has led to a decrease in the speed of these local breezes. The results also showed that Lake Urmia increases minimum temperature, vapor pressure, dewpoint temperature, and relative humidity, and decreases maximum temperature and evaporation, in local regions around the lake. These effects of the lake on the local climate increase with increasing air temperature, so the lake has its most significant impact on the local climate in summer and the least in winter. Changes in climate variables following the dramatic decline in water levels in Lake Urmia in recent years were assessed by dividing the study period into sub-periods, before and after 1995, and comparing climate variables between sub-periods and stations. The results indicated that the local climate is still affected by the lake, but that the level of influence of the lake on the local climate has decreased with declining lake water level.

Supplementary Materials: The following are available online at http://www.mdpi.com/2073-4441/12/8/2153/s1, Figure S1: Seasonal patterns in relative humidity. Scatter plots of relative humidity at (a) 03:00 h and (c) $15.00 \mathrm{~h}$ in the different seasons at Urmia station $(\mathrm{U})$ and Saqez station $(\mathrm{S})$. (b,d) The corresponding boxplots. Figure S2: Changes in the hourly speed of local lake and land breezes at Urmia meteorological station in the periods with normal and low lake level. Figure S3: Changes in hourly climate parameters at Urmia (U) and Saqez (S) meteorological stations in low water level in Lake Urmia period compare to normal water level. (a) Temperature in summer, $(b)$ temperature in winter, $(c)$ vapor pressure in summer, $(d)$ vapor pressure in winter, (e) dewpoint temperature in summer, $(\mathrm{f})$ dewpoint temperature in winter, $(\mathrm{g})$ relative humidity in summer, and (h) relative humidity in winter. Table S1: Geographical locations of the meteorological stations from which data were obtained for this study. Table S2: Wind clustering during the day and night at Urmia meteorological station in summer.

Author Contributions: Conceptualization, A.H.D. and M.T.; methodology, A.H.D., D.M.P. and H.M.; software, A.H.D. and H.M.; validation, A.H.D., D.M.P., and M.T.; formal analysis, A.H.D. and D.M.P.; investigation, Z.K. and M.T.; resources, A.H.D. and M.T.; data curation, H.M.; writing—original draft preparation, A.H.D., D.M.P., and H.M.; writing—review and editing, Z.K.; visualization, A.H.D. and H.M.; supervision, Z.K.; project administration, M.T. All authors have read and agreed to the published version of the manuscript.

Funding: This research did not receive any specific grant from funding agencies in the public, commercial, or not-for-profit sectors.

Acknowledgments: We are grateful to the Urmia Lake Restoration Program (ULRP) and to I.R. of Iran Meteorological Organization (IRIMO) for providing the primary data for this study.

Conflicts of Interest: The authors declare no conflict of interest.

\section{References}

1. Bai, J.; Lu, Q.; Zhao, Q.; Wang, J.; Ouyang, H. Effects of Alpine Wetland Landscapes on Regional Climate on the Zoige Plateau of China. Adv. Meteorol. 2013, 2013, 1-7. [CrossRef]

2. Borja, S.; Kalantari, Z.; Destouni, G. Global Wetting by Seasonal Surface Water Over the Last Decades. Earth's Future 2020, 8. [CrossRef]

3. Kalantari, Z.; Ferreira, C.; Page, J.; Goldenberg, R.; Olsson, J.; Destouni, G. Meeting sustainable development challenges in growing cities: Coupled social-ecological systems modeling of land use and water changes. J. Environ. Manag. 2019, 245, 471-480. [CrossRef] [PubMed]

4. Notaro, M.; Zarrin, A.; Vavrus, S.; Bennington, V. Simulation of Heavy Lake-Effect Snowstorms across the Great Lakes Basin by RegCM4: Synoptic Climatology and Variability. Mon. Weather. Rev. 2013, 141, 1990-2014. [CrossRef]

5. Scott, R.W.; Huff, F.A. Impacts of the Great Lakes on Regional Climate Conditions. J. Great Lakes Res. 1996, 22, 845-863. [CrossRef]

6. De Niet, J.; Finger, D.; Bring, A.; Egilson, D.; Gustafsson, D.; Kalantari, Z. Benefits of Combining Satellite-Derived Snow Cover Data and Discharge Data to Calibrate a Glaciated Catchment in Sub-Arctic Iceland. Water 2020, 12, 975. [CrossRef] 
7. Wuebbles, D.; Cardinale, B.; Cherkauer, K.; Davidson-Arnott, R.; Hellmann, J.; Infante, D.; Ballinger, A. An Assessment of the Impacts of Climate Change on the Great Lakes. Environ. Law Policy Cent. 2019. Available online: http://elpc.org/wp-content/uploads/2019/03/Great-Lakes-Climate-Change-Report.pdf (accessed on 29 July 2020).

8. Shafir, H.; Alpert, P. Regional and local climatic effects on the Dead-Sea evaporation. Clim. Chang. 2010, 105, 455-468. [CrossRef]

9. Şimşek, Ç.K.; Ödül, H. Investigation of the effects of wetlands on micro-climate. Appl. Geogr. 2018, 97, 48-60. [CrossRef]

10. AghaKouchak, A.; Norouzi, H.; Madani, K.; Mirchi, A.; Azarderakhsh, M.; Nazemi, A.; Nasrollahi, N.; Farahmand, A.; Mehran, A.; Hasanzadeh, E. Aral Sea syndrome desiccates Lake Urmia: Call for action. J. Great Lakes Res. 2015, 41, 307-311. [CrossRef]

11. Khazaei, B.; Khatami, S.; Alemohammad, S.H.; Rashidi, L.; Wu, C.; Madani, K.; Kalantari, Z.; Destouni, G.; AghaKouchak, A. Climatic or regionally induced by humans? Tracing hydro-climatic and land-use changes to better understand the Lake Urmia tragedy. J. Hydrol. 2019, 569, 203-217. [CrossRef]

12. Dehghanipour, A.H.; Zahabiyoun, B.; Schoups, G.; Babazadeh, H. A Weap-Modflow surface water-groundwater model for the irrigated Miyandoab plain, Urmia lake basin, Iran: Multi-objective calibration and quantification of historical drought impacts. Agric. Water Manag. 2019, 223, 105704. [CrossRef]

13. Hosseini-Moghari, S.; Araghinejad, S.; Tourian, M.J.; Ebrahimi, K.; Döll, P. Quantifying the impacts of human water use and climate variations on recent drying of Lake Urmia basin: The value of different sets of spaceborne and in situ data for calibrating a global hydrological model. Hydrol. Earth Syst. Sci. 2020, 24, 1939-1956. [CrossRef]

14. Panahi, D.M.; Kalantari, Z.; Ghajarnia, N.; Seifollahi-Aghmiuni, S.; Destouni, G. Variability and change in the hydro-climate and water resources of Iran over a recent 30-year period. Sci. Rep. 2020, 10, 1-9. [CrossRef]

15. Schulz, S.; Darehshouri, S.; Hassanzadeh, E.; Tajrishy, M.; Schüth, C. Climate change or irrigated agriculture-What drives the water level decline of Lake Urmia. Sci. Rep. 2020, 10, 1-10. [CrossRef]

16. Chaudhari, S.; Felfelani, F.; Shin, S.; Pokhrel, Y. Climate and anthropogenic contributions to the desiccation of the second largest saline lake in the twentieth century. J. Hydrol. 2018, 560, 342-353. [CrossRef]

17. Dehghanipour, A.H.; Schoups, G.; Zahabiyoun, B.; Babazadeh, H. Meeting agricultural and environmental water demand in endorheic irrigated river basins: A simulation-optimization approach applied to the Urmia Lake basin in Iran. Agric. Water Manag. 2020, 241, 106353. [CrossRef]

18. Tourian, M.J.; Elmi, O.; Chen, Q.; Devaraju, B.; Roohi, S.; Sneeuw, N. A spaceborne multisensor approach to monitor the desiccation of Lake Urmia in Iran. Remote Sens. Environ. 2015, 156, 349-360. [CrossRef]

19. Delju, A.H.; Ceylan, A.; Piguet, E.; Rebetez, M. Observed climate variability and change in Urmia Lake Basin, Iran. Theor. Appl. Clim. 2012, 111, 285-296. [CrossRef]

20. Bai, J.; Chen, X.; Yang, L.; Fang, H. Monitoring variations of inland lakes in the arid region of Central Asia. Front. Earth Sci. 2012, 6, 147-156. [CrossRef]

21. Laaha, G.; Blöschl, G. Seasonality indices for regionalizing low flows. Hydrol. Process. 2006, 20, 3851-3878. [CrossRef]

22. Alizadeh-Choobari, O.; Ahmadi-Givi, F.; Mirzaei, N.; Owlad, E. Climate change and anthropogenic impacts on the rapid shrinkage of Lake Urmia. Int. J. Clim. 2016, 36, 4276-4286. [CrossRef]

(C) 2020 by the authors. Licensee MDPI, Basel, Switzerland. This article is an open access article distributed under the terms and conditions of the Creative Commons Attribution (CC BY) license (http://creativecommons.org/licenses/by/4.0/). 